\title{
Productivity of energy sorghum irrigated with reclaimed wastewaters
}

\author{
Pasquale Campi, ${ }^{1}$ Alejandra Navarro, ${ }^{1}$ A. Domenico Palumbo, ${ }^{1}$ Michele Solimando, ${ }^{2}$ \\ Antonio Lonigro, ${ }^{3}$ Marcello Mastrorilli ${ }^{1}$ \\ ${ }^{1}$ Consiglio per la Ricerca e la Sperimentazione in Agricoltura, Unità di Ricerca per i Sistemi \\ Colturali degli Ambienti caldo-aridi, Bari; ${ }^{2}$ Consorzio per la Bonifica della Capitanata, Foggia; \\ ${ }^{3}$ Dipartimento di Scienze Agro-Ambientali e Territoriali, Università di Bari, Italy
}

\begin{abstract}
The sustainability of biomass sorghum (Sorghum bicolor L. Moench.) in the Mediterranean environment is linked to the possibility of increasing crop productivity by using conventional clean water and wastewater irrigation. An experimental setup was arranged in Southern Italy during 2012 and 2013 seasons to determine the potential productivity of biomass sorghum irrigated with conventional water at different irrigation regimes (100 and 50\% of calculated evapotranspiration) and different types of municipal wastewater. During the sorghum growing season, the crop development (biomass and leaf are index) and the soil water content were monitored for all irrigation treatments. The data obtained showed that the dry biomass of sorghum irrigated with the deficit treatment $\left(17 \mathrm{t} \mathrm{ha}^{-1}\right)$ was lower compared with conventionally irrigated sorghum. For both seasons and under full irrigated conditions, sorghum irrigated with wastewater produced on average more dry biomass $\left(23 \mathrm{tha}^{-1}\right)$ than the crop irrigated with conventional water $\left(20.5 \mathrm{t} \mathrm{ha}^{-1}\right)$, using the same irrigation volumes.
\end{abstract}

Correspondence: Pasquale Campi, Consiglio per la Ricerca e la Sperimentazione in Agricoltura, Unità di Ricerca per i Sistemi Colturali degli Ambienti caldo-aridi (CRA-SCA), via Celso Ulpiani 5, 70125 Bari, Italy. Tel. +39.080 .5475014 - Fax: +39.080 .5475023 .

E-mail: pasquale.campi@entecra.it

Key words: biomass for energy, evapotranspiration, water quality, soil contamination.

Conference presentation: SIA XLII Congress, Reggio Calabria, 2013.

Acknowledgments: the authors are grateful to the Italian Ministry of University and Research (MIUR or Ministero Italiano dell'Università e della Ricerca) for its financial support from the Project In. T.e.R.R.A. (contract No 01_01480) co-funded within the Italian Program PON/Ricerca $e$ Competitività 2007-2013.

Received for publication: 14 January 2014.

Revision received: 12 June 2014.

Accepted for publication: 14 June 2014.

CC Copyright P. Campi et al., 2014

Licensee PAGEPress, Italy

Italian Journal of Agronomy 2014; 9:577

doi:10.4081/ija.2014.577

This article is distributed under the terms of the Creative Commons Attribution Noncommercial License (by-nc 3.0) which permits any noncommercial use, distribution, and reproduction in any medium, provided the original author(s) and source are credited.

\section{Introduction}

Sorghum (Sorghum bicolor L. Moench.), a C4 species (using the malate cycle) of tropical origin, is the fifth most important cereal crop in the world and can be used as green fodder, thatch and silage as well as to produce syrup and fuel (ethanol). It is grown in 99 countries across the world on 44 million hectares, mainly in areas which are too dry for corn production.

Compared with other crops, sorghum is more environmentally sustainable (Dalianis, 1996), particularly because of its relatively low nitrogen (Dercas et al., 1995) and water requirements (Steduto et al., 1997; Mastrorilli et al., 1999; Vasilakoglou et al., 2011) and its high efficiency in transforming consumed water and captured energy into dry matter.

The interest in sorghum for areas of Southern Europe is related to its potential as an energy crop, due to the sugar content in the stem suitable to produce bio-ethanol fuel, its high growth rate and its biomass energy value (Zegada-Lizarazu and Monti, 2012).

The European Union indicates that the use of biofuels, which is currently at $10 \%$, should be increased in the energy mix including fossil fuels by 2020 (European Commission, 2009). In this respect, sweet sorghum may be used to produce bioethanol directly from the sucrose contained its stems and also from its lignocellulosic biomass, after stem sucrose extraction, as a second-generation biofuel (Cosentino et al., 2012).

According to Almodares and Hadi (2009), sorghum used for bioethanol production can be an alternative crop to corn in areas where water availability is limited during the growing season. Despite the yield potential of sorghum as an energy crop has been repeatedly highlighted (Smith and Doran, 1996; Steduto et al., 1997), the agricultural techniques for production under limited water conditions require further investigations (Vasilakoglou et al., 2011). This is a crucial point in the pedo-climatic context of Mediterranean Europe where high temperatures and high solar radiation are favourable to sorghum ecophysiology, however the scarcity of water resources limits its cultivation unless a suitable exploitation plan of the available water resources (included wastewaters) is developed and alternative irrigation strategies (regulated deficit irrigation) to optimise the biomass yields are developed.

This study compares yields from sweet sorghum irrigated with controlled water stress and wastewater at different refining degrees, in a typical semi-arid environment.

The main obstacle to the reuse of wastewater for irrigation is due to the strict limits imposed by national and regional laws issued for preventing sanitary and hygienic risks in relation to its use. However it should be taken into account that, contrary to what is prescribed by law, the irrigation of energy crops does not require the same water quality needed for food crops.

Furthermore the law does not consider that specific cropping systems can be designed expressly for soil decontamination. In particular, 
the sorghum crop demonstrated a quite good capacity for uptaking heavy metals from contaminated soil by accumulating lead in leaves and cadmium, zinc ( $\mathrm{Zn})$ and copper $(\mathrm{Cu})$ in stems (Zhuang et al., 2009).

Considering the potential of sweet sorghum as an energy crop, and the importance of reclaimed wastewater as an alternative water resource, this study aims to assess from the agronomic perspective if a reduced level of wastewater treatment is compatible with sweet sorghum productivity.

\section{Materials and methods}

The experimental trials were conducted during the 2012 and 2013 seasons in a private farm located in Southern Italy (Trinitapoli, lat. $41^{\circ}$ $21^{\prime}$, long. $16^{\circ} 03$ ', alt. $0 \mathrm{~m}$ asl), close a municipal wastewater treatment plant which supplied different qualities of reclaimed water for irrigation during the two growing seasons.

The site has a Mediterranean climate characterised by warm and dry summers, with a maximum air temperature ranging from $32^{\circ} \mathrm{C}$ to $43^{\circ} \mathrm{C}$ and a minimum relative humidity ranging from $40 \%$ to $15 \%$ (Campi $e t$ al., 2009). Precipitations are mainly concentrated in the autumn and late winter, whereas rain is greatly reduced or absent in the springsummer period. The annual average rainfall at this site was $554 \mathrm{~mm}$.

The soil texture is classified as clay-loam (33\% clay, $34 \%$ silt and $33 \%$ sand) according to the United States Department of Agriculture (USDA) Classification, and the water contents (\% of water respect to the dry soil in volume) at the field capacity and at the wilting point were $38 \%$ and $26 \%$, respectively (measured using the Richards chambers). The soil water reserve was moderate $(180 \mathrm{~mm})$, because the rhizo-sphere does not develop below $1.5 \mathrm{~m}$ in this soil.

The soil showed a good chemical fertility (Table 1) with an adequate supply of total $\mathrm{N}\left(1.5 \mathrm{~g} \mathrm{~kg}^{-1}\right)$ and organic carbon $\left(14 \mathrm{~g} \mathrm{~kg}^{-1}\right)$ and a high content of phosphorus (P) (71 $\left.\mathrm{mg} \mathrm{kg}^{-1}\right)$ that can be assimilated.

The KWS Bulldozer hybrid was used for the field experiment. It is characterised by a medium-late vegetative cycle, high size, good tolerance to bending, and high yields in dry and green biomass.

Sorghum was sown on May $28^{\text {th }}, 2012$ and May $21^{\text {th }}, 2013$ with a plant density of 18 plants $\mathrm{m}^{-2}$, and grown with agricultural techniques aimed to reduce energy inputs: weeding control at the initial stage of the crop and nitrogen fertilisation of $100 \mathrm{~kg} \mathrm{~N} \mathrm{ha}^{-1}$ after 30 days from sowing. During the crop cycle there was a substantial absence of phyto-sanitary injuries (with the exception of a sporadic presence of aphid colonies), thus avoiding the use of any pesticide treatment.

Sorghum plants were submitted to the following irrigation treatments:

- Conventional water supplied from the water network of the wastewater plant Consorzio di Bonifica della Capitanata and straight from Marana Capacciotti dam restoring $100 \%$ of the field capacity (AC100).

- Conventional water restoring $50 \%$ of the field capacity (AC50) only for the 2012 season.

- Purified and refined municipal wastewater from the reclaimed wastewater plant of Trinitapoli with membrane filtration technology, restoring $100 \%$ of the water lost through evapotranspiration (AF).

- Purified wastewater withdrawn before completing to reclamation treatment and derived from the secondary treatment, restoring $100 \%$ of water lost by evapotranspiration (AS).

Irrigation treatments were arranged in a complete randomised experimental design, where blocks of $400 \mathrm{~m}^{2}$ were replicated 3 times.

During the two irrigation seasons, the supplied waters were characterised by the following parameters: electrical conductivity, $\mathrm{pH}$, biolog- ical oxygen demand, chemical oxygen demand, chlorine, anions $\left(\mathrm{F}^{-}, \mathrm{Cl}^{-}\right.$, $\left.\mathrm{NO}_{3}{ }^{-}, \mathrm{P}_{2} \mathrm{O}_{4}^{--}\right)$, cations $\left(\mathrm{Na}^{+}, \mathrm{K}^{+}, \mathrm{Ca}^{++}, \mathrm{Mg}^{++}, \mathrm{NH}_{4}^{+}\right)$and sodium adsorption ratio.

The irrigation water was scheduled once per week by a drip irrigation system, supplying the amount of water lost by evapotranspiration (ETc). The irrigation volume was calculated according the FA0-56 methodology (Allen et al., 1998), supplying ETc calculated in the previous 7-day period.

Daily soil water content in the whole soil profile $\left(\mathrm{mm} \mathrm{d}^{-1}\right)$ was monitored by capacitive probes.

Capacitive probes (10HS; Decagon Devices Inc., Pullman, WA, USA) were installed horizontally into the soil in two layers $(-0.3$ and $-0.6 \mathrm{~m})$ in only one block of AC100 (in 2012 and 2013) and AC50 treatments (in 2012 season). The probes were connected to a data logger [Grillo MMS; Tecno.EL srl, San Matteo della Decima (B0), Italy]. A local calibration was used to calculate the volumetric soil water content.

The differentiation of the irrigation treatments (AC100 and AC50) started 30 days after sowing, in order to sustain the crop development also during the early growth stages of the AC50 treatment. During the 2012 season the irrigation volumes were $300 \mathrm{~mm}$ for treatments $\mathrm{AC} 100$, $\mathrm{AF}$ and $\mathrm{AS}$, and $200 \mathrm{~mm}$ for AC50, while during the 2013 season the irrigation volumes were $340 \mathrm{~mm}$.

At regular intervals (every 7-10 days) leaf area index (LAI) and dry biomass were measured. The LAI was measured by area (LAI-2000 Plant Canopy Analyzer; Li-Cor, Lincoln, NE, USA) and the dry matter was determined on sampled plants by using a dry-oven (at $65^{\circ} \mathrm{C}$ for 48 h). At the end of the sorghum cycle (on second week of September) all plants were harvested from $20 \mathrm{~m}^{2}$ plots, and the above ground biomass was determined.

The production data were statistically analysed by ANOVA using the software Statgraphics Plus 5.1 (Statpoint Technologies, Inc., Warrenton, VA, USA).

The seasonal irrigation volumes (I) and sorghum yield data were used to determine the irrigation water use efficiency (IWUE) for the different treatments, according to the following formula:

$$
\operatorname{IWUE}\left(\mathrm{kg} \cdot \mathrm{m}^{-3}\right)=\frac{\operatorname{yield}\left(\mathrm{kg} \cdot \mathrm{m}^{-2}\right)}{I\left(\mathrm{~m}^{3} \cdot \mathrm{m}^{-2}\right)}
$$

Table 1. Main physical-chemical characteristics of the soil.

\begin{tabular}{|c|c|c|c|c|}
\hline \multirow[t]{3}{*}{ Parameter } & \multicolumn{4}{|c|}{ Depth (P) } \\
\hline & \multicolumn{2}{|c|}{$0-0.20 \mathrm{~m}$} & \multicolumn{2}{|c|}{$0.21-0.40 \mathrm{~m}$} \\
\hline & Average & SE & Average & SE \\
\hline Clay (\%) & 32.5 & 3.6 & 32.9 & 3.2 \\
\hline Silt (\%) & 36.1 & 2.3 & 35.0 & 1.7 \\
\hline Sand (\%) & 32.9 & 0.3 & 32.1 & 0.4 \\
\hline $\mathrm{EC}\left(\mathrm{dS} \mathrm{m} \mathrm{m}^{-1}\right)$ & 1.10 & 0.14 & 1.37 & 0.23 \\
\hline $\mathrm{pH}$ & 8.08 & 0.24 & 8.25 & 0.10 \\
\hline Total limestone (\%) & 17.2 & 1.11 & 20.2 & 0.73 \\
\hline Active limestone $\left(\mathrm{g} \mathrm{kg}^{-1}\right)$ & 9.85 & 0.49 & 9.93 & 0.59 \\
\hline $\mathrm{C}\left(\mathrm{g} \mathrm{kg}^{-1}\right)$ & 14.03 & 0.58 & 13.76 & 0.58 \\
\hline $\mathrm{N}\left(\mathrm{g} \mathrm{kg}^{-1}\right)$ & 1.52 & 0.04 & 1.43 & 0.07 \\
\hline$P\left(\mathrm{mg} \mathrm{kg}^{-1}\right)$ & 79.75 & 5.3 & 62.21 & 13.73 \\
\hline $\mathrm{Ca}\left(\mathrm{mg} \mathrm{kg}^{-1}\right)$ & 3285.51 & 40.39 & 3283.02 & 67.13 \\
\hline $\mathrm{Na}\left(\mathrm{mg} \mathrm{kg}^{-1}\right)$ & 180.21 & 12.27 & 231.59 & 32.39 \\
\hline
\end{tabular}

P, phosporus; SE, standard error; EC, electrical conductivity; C, carbon; N, nitrogen; $\mathrm{Ca}$, calcium; Na, sodium. 


\section{Results and discussion}

The experimental design ensures a clear differentiation of the water status of the soil as a function of the supplied water volume (Figure 1). At the end of the sorghum cycle (85 days after sowing), when irrigations were interrupted, the differences in soil water content between the irrigation treatments were reduced.

In the 2012 season (Figure 1A), the volumetric soil water content monitored in the AC100 treatment achieved a field capacity after rain events or irrigation. The irrigation scheduling prevented the values of the soil water content from being lower than the readily available water (RAW) threshold $\left(0.32 \mathrm{~m}^{3} \mathrm{~m}^{-3}\right)$. In the AC50 treatment the values of the soil water content went below the RAW threshold and reached the wilting point for limited periods, therefore the crop has experienced temporary soil water stress. In the 2013 season (Figure 1B), the soil water content values of the AC100 treatment were similar to those recorded during the previous season.

The growth parameters were measured periodically as LAI (Figure 2) and dry biomass (Figure 3 ). The irrigation regimes affected the development of the crop. Data of LAI and dry biomass have followed the same trends. In particular, significant differences in growth appeared in July, during the stem elongation phase of sorghum.

The LAI values were proportional to the irrigation treatments. During the 2012 season (Figure 2A), reduced irrigation did not prevent sorghum from achieving the complete volume of the cycle crop. The limited irrigation supply induced a reduction of $35 \%$ of the maximum LAI values compared with the AC100 treatment, and a $42 \%$ reduction compared with the wastewater treatments (AF and AS). These data
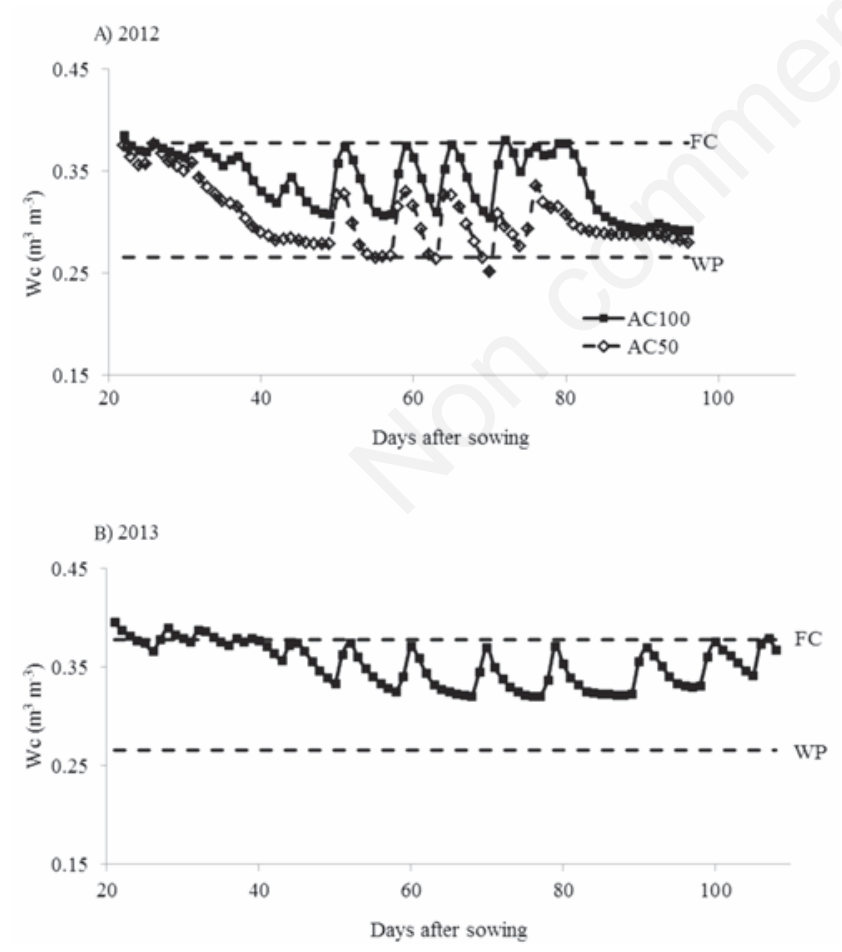

Figure 1. Water content (Wc) of the soil as a function of the water regime during the 2012 and 2013 seasons. The dashed lines correspond to the water contents of the soil at field capacity (FC) and at wilting point (WP). AC100, conventional water restoring $100 \%$ of the field capacity; $\mathrm{AC} 50$, conventional water restoring $50 \%$ of the field capacity; AF, purified water; AS, secondary water.
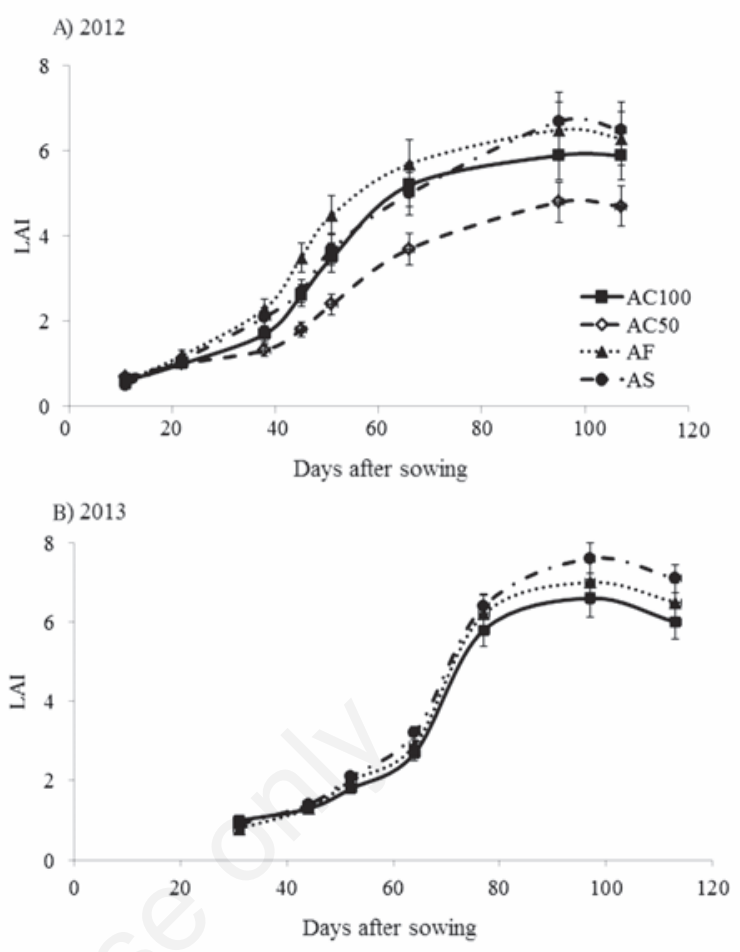

Figure 2. Leaf area index of sorghum for four water regimes and two seasons. AC100, conventional water restoring $100 \%$ of the field capacity; AC50, conventional water restoring $50 \%$ of the field capacity; AF, purified water; AS, secondary water.
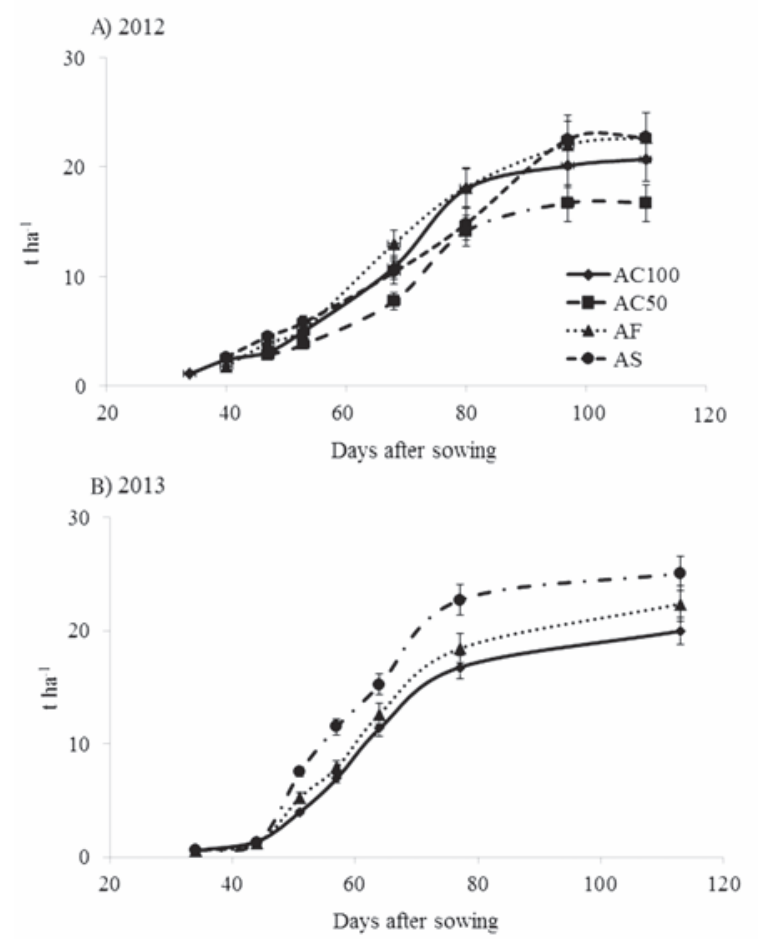

Figure 3. Dry biomass of sorghum for four water regimes and two seasons. AC100, conventional water restoring $100 \%$ of the field capacity; AC50, conventional water restoring $50 \%$ of the field capacity. 
confirm that hybrids of sorghum biomass tolerate a mild water stress (Mastrorilli et al., 2011). During the 2013 season (Figure 2B), the AS and $\mathrm{AF}$ treatments induced respectively an increase by $15 \%$ and $8 \%$ of the maximum LAI values in comparison with the AC100 treatment.

The highest production of dry matter was observed for the plants irrigated with the wastewaters (AF or AS) in both seasons. In the 2012 season these values were significantly higher than $2 \mathrm{t} \mathrm{ha}^{-1}$ or $4 \mathrm{t} \mathrm{ha}^{-1}$ with respect to sorghum irrigated with conventional water at the rate of $100 \%$ or $50 \%$ of ET (AC100 and AC50). Biomass production in treatment AC50 was $20 \%$ and $30 \%$ lower than that obtained by sorghum irrigated with $100 \%$ of ET using conventional water and wastewater, respectively. In the 2013 season, biomass production with treatment

Table 2. Dry biomass sorghum yield $\left(\mathrm{t} \mathrm{ha}^{-1}\right)$ for two seasons.

\begin{tabular}{lcc} 
Treatments & 2012 & 2013 \\
AC100 & $20.8^{\mathrm{ab}}$ & $20.0^{\mathrm{c}}$ \\
$\mathrm{AC50}$ & $16.7^{\mathrm{b}}$ & - \\
\hline $\mathrm{AS}$ & $22.6^{\mathrm{a}}$ & $25.1^{\mathrm{a}}$ \\
AF & $22.7^{\mathrm{a}}$ & $22.4^{\mathrm{b}}$ \\
\hline a,b,c The means without any letters in common are significantly different $(\mathrm{P} \leq 0.05)$, according to the \\
$\begin{array}{l}\text { Tukey test. AC100, conventional water restoring } 100 \% \text { of the field capacity; AC50, conventional water } \\
\text { restoring 50\% of the field capacity; AF, purified water; AS, secondary water. }\end{array}$
\end{tabular}

Table 3. Efficiency of irigation water use $\left(\mathrm{kg} \mathrm{m}^{-3}\right)$ of sorghum under 4 water treatments for two seasons.

\begin{tabular}{lcc} 
Treatments & 2012 & 2013 \\
$\mathrm{AC} 100$ & $6.9^{\mathrm{c}}$ & $6.1^{\mathrm{c}}$ \\
$\mathrm{AC} 50$ & $8.3^{\mathrm{a}}$ & - \\
$\mathrm{AS}$ & $7.5^{\mathrm{b}}$ & $7.6^{\mathrm{a}}$ \\
$\mathrm{AF}$ & $7.5^{\mathrm{b}}$ & $6.8^{\mathrm{b}}$ \\
\hline
\end{tabular}

a,b,c The means without any letters in common are significantly different $(\mathrm{P} \leq 0.05)$, according to the Tukey test. AC100, conventional water restoring $100 \%$ of the field capacity; AC50, conventional water restoring $50 \%$ of the field capacity; AF, purified water; $\mathrm{AS}$, secondary water.
AC100 was significantly less, i.e. $5.1 \mathrm{t} \mathrm{ha}^{-1}$ or $2.1 \mathrm{t} \mathrm{ha}^{-1}$, with respect to that obtained by sorghum irrigated with wastewater from secondary (AS) and purified wastewater (AF), respectively (Table 2).

The highest yield recorded under well-watered conditions was similar to the yields reported in literature (Curt et al., 1998; Mastrorilli et al., 1999; Dercas and Liakatas, 2007) and also the effects of deficit irrigation on yield is in agreement with the yields reported by other studies carried out in similar environments. In particular, Cosentino et al. (2012) showed that a $38 \%$ reduction of used water determined a $22 \%$ reduction in yield. In fact, higher performance observed by restoring the $100 \%$ ETc indicates that any effort to maximise sorghum biomass productivity might be subordinated to an adequate water supply (Habyarimana et al., 2004).

The irrigation water use efficiency values (Table 3) have shown significant differences with the different treatments. The highest value of IWUE was calculated in the deficit irrigation treatment (2012). In terms of water quality, irrigation with wastewater has determined high values of IWUE in both seasons. Therefore these results show that it is preferable to irrigate with wastewater, because it allows both high values of IWUE and high production of biomass. Whereas in the case of irrigation deficit, the high values of IWUE are associated with a low production in biomass.

The best response in terms of growth and production was observed in AF and AS treatments and depends on the higher quantity of nutrient uptake, when wastewater is used for irrigation. For instance, in terms of contributions of $\mathrm{N}$ in nitrate during the two seasons, the average concentrations reported for conventional, secondary and refined waters amounted to 4, 10.5 and $3.5 \mathrm{mg} \mathrm{L}^{-1} \mathrm{di} \mathrm{NO}_{3}{ }^{-}$(Table 4), corresponding to concentrations of $0.9,2.4$ and $0.8 \mathrm{mg} \mathrm{L}^{-1} \mathrm{di} \mathrm{N}$, respectively.

The average $\mathrm{N}$ supplied with irrigation during the growing seasons (2012 and 2013) was of 2.8, 7.6 and $2.6 \mathrm{~kg} \mathrm{ha}^{-1}$ of $\mathrm{N}$ for the AC, AS and AF treatments, respectively, while P supplied with irrigation water was 7,32 and $24 \mathrm{~kg} \mathrm{ha}^{-1}$ of $\mathrm{P}$ for the AC, AS and AF treatments, respectively (Table 4). During the 2012 survey, the $\mathrm{N}$ concentration of two water samples (from AS and AF) was higher than $290 \mathrm{mg} \mathrm{L}^{-1}$. These values are exceptionally high and are probably due to a temporary interruption of ordinary operation of the wastewater treatment plant. However,

Table 4. Main chemical properties of the 3 water treatments. Average values of water sampled from May to September 2012 and from May to September 2013.

\begin{tabular}{|c|c|c|c|c|c|c|c|}
\hline \multicolumn{2}{|c|}{ Chemical properties } & \multicolumn{3}{|c|}{2012} & \multicolumn{3}{|c|}{2013} \\
\hline & & AC100 & AS & $\mathrm{AF}$ & $\mathrm{AC} 100$ & AS & $\mathrm{AF}$ \\
\hline $\mathrm{EC}$ & $\mathrm{dS} / \mathrm{m}$ & 0.64 & 1.52 & 1.47 & 0.62 & 1.33 & 1.31 \\
\hline $\mathrm{pH}$ & & 7.65 & 7.57 & 7.63 & 7.3 & 7.3 & 7.44 \\
\hline $\mathrm{BOD}_{5}$ & $\mathrm{mgO}_{2} / \mathrm{L}$ & 6 & 40 & 22 & 3 & 49 & 6 \\
\hline COD & $\mathrm{mgO}_{2} / \mathrm{L}$ & 0 & 166 & 135 & 10 & 103 & 43 \\
\hline Active $\mathrm{Cl}^{-}$ & $\mathrm{mg} / \mathrm{L}$ & 0 & 0 & 0 & 0 & 10 & 0.5 \\
\hline $\mathrm{Na}^{+}$ & $\mathrm{mg} / \mathrm{L}$ & 48 & 128 & 119 & 31 & 103 & 104 \\
\hline $\mathrm{K}^{+}$ & $\mathrm{mg} / \mathrm{L}$ & 0 & 22 & 23 & 7 & 28 & 29 \\
\hline $\mathrm{Ca}^{2+}$ & $\mathrm{mg} / \mathrm{L}$ & 51 & 83 & 92 & 48 & 122 & 116 \\
\hline $\mathrm{Mg}^{2+}$ & $\mathrm{mg} / \mathrm{L}$ & 12 & 21 & 20 & 8 & 16 & 21 \\
\hline $\mathrm{NH}^{4+}$ & $\mathrm{mg} / \mathrm{L}$ & 2 & 46 & 41 & 0.5 & 37 & 26 \\
\hline $\mathrm{Cl}^{-}$ & $\mathrm{mg} / \mathrm{L}$ & 53 & 182 & 197 & 25 & 143 & 138 \\
\hline $\mathrm{F}^{-}$ & $\mathrm{mg} / \mathrm{L}$ & 1 & 1 & 0 & 0.5 & 2 & 1.6 \\
\hline $\mathrm{NO}_{3}^{-}$ & $\mathrm{mg} / \mathrm{L}$ & 5 & 11 & 3 & 3 & 10 & 4 \\
\hline $\mathrm{PO}_{4}{ }^{2-}$ & $\mathrm{mg} / \mathrm{L}$ & 0 & 23 & 25 & 18 & 22 & 10 \\
\hline SAR & & 2 & 3 & 3 & 1 & 2 & 2 \\
\hline
\end{tabular}

AC100, conventional water restoring $100 \%$ of the field capacity; AF, purified water; $\mathrm{AS}$, secondary water; $\mathrm{EC}$, electrical conductivity; $\mathrm{BOD}_{5}$, biological oxygen demand; $\mathrm{COD}$, chemical oxygen demand; Na ${ }^{+}, \mathrm{K}^{+}, \mathrm{Ca}^{2+}$, $\mathrm{Mg}^{2+}, \mathrm{NH}_{4}{ }^{+}$, cations; $\mathrm{Cl}^{-}, \mathrm{F}^{-}, \mathrm{NO}_{3}{ }^{-}, \mathrm{P}_{2} \mathrm{O}_{4}{ }^{2-}$, anions; $\mathrm{SAR}$, sodium adsorption ratio. 
these values were not considered in the average 2012 data for $\mathrm{N}$ concentration in the reclaimed waters reported in Table 4.

These quantities are to be considered in addition to $\mathrm{N}$ supplied as ammonium for fertilisation. Nitrogen supplied to the soil by wastewater does not cause an environmental issue, because sorghum uptake determines a great reduction in nitrate concentration of soil water (Cosentino et al., 2012).

These results are confirmed by the tissue analysis of the plant, sampled in the 2012 season. The concentrations of $\mathrm{N}$ in plant tissues of the AS treatment are significantly higher $(\mathrm{P}=0.0023)$ than those of the $\mathrm{AF}$

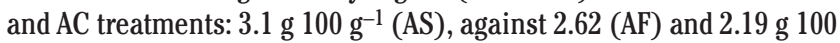
$\mathrm{g}^{-1}(\mathrm{AC})$. No significant differences were found between treatments in relation to the heavy metal content, such as $\mathrm{Zn}(\mathrm{P}=0.6568)$ and $\mathrm{Cu}$ $(\mathrm{P}=0.7543)$. However, concentrations of heavy metals in soil and crops were lower than those indicated by the law (Lonigro et al., 2007). The uptake of heavy metals depends on the sorghum genotype (Zhang et al., 2002). Jamali et al. (2008) showed the accumulation of heavy metals among five varieties of sorghum. The results concerning the accumulation capacity of heavy metals by Bulldozer are reported in the literature.

\section{Conclusions}

The scarce water resources demand new strategies for using water in agriculture. This is a crucial step for the agronomic management of the energy crops, since their environmental and economic sustainability relies on the reduction of agronomic inputs. This research shows original results regarding the application of wastewater on dedicated energy crops in the Mediterranean area and indeed has considered possible ways to irrigate energy sorghum in a sustainable way via the use of wastewater and deficit irrigation. In fact, the use of wastewater, even with a reduced reclaimed treatment (AS), increased production (for an additional contribution of nutrients) without adding heavy metals in the environment.

Adequately treated wastewaters can be used for irrigation and represent a valid alternative to conventional waters. However, although the production strategy showed positive results in the case of energy sorghum, public heath related aspects should be considered mainly regarding the possible presence of protozoan parasites in the soil.

\section{References}

Allen RG, Pereira LS, Raes D, Smith M, 1998. Crop evapotranspiration: guidelines for computing crop water requirements. FAO Irrigation and Drainage paper No. 56, Rome, Italy.

Almodares A, Hadi MR, 2009. Production of bioethanol from sweet sorghum: a review. Afr. J. Agric. Res. 4:772-80.

Campi P, Palumbo AD, Mastrorilli M, 2009. Effects of tree windbreak on microclimate and wheat productivity in a Mediterranean environment. Eur. J. Agron. 30:220-7.

Cosentino L, Mantineo M, Testa G, 2012. Water and nitrogen balance of sweet sorghum (Sorghum bicolor Moench [L.]) cv. Keller under semi-arid conditions. Ind. Crops Prod. 36:329-42.

Curt MD, Fernandez J, Martinez M, 1995. Productivity and water use efficiency of sweet sorghum (Sorghum bicolor (L.) Moench) cv.
Keller in relation to water regime. Biomass Bioenerg. 8:401-9.

Dalianis C, 1996. Adaptation, productivity and agronomic aspects of sweet sorghum under EU conditions. Proc. 1st European Seminar on Sorghum for Energy and Industry, 1-3 April 1996, Toulouse, France, pp 15-25.

Dercas N, Liakatas A, 2007. Water and radiation effect on sweet sorghum productivity. Water Resour. Manage. 2:1585-600.

Dercas N, Panoutsou C, Dalianis C, Sooter C, 1995. Sweet Sorghum (Sorghum bicolor [L.] Moench) response to four irrigation and two nitrogen fertilization rates. In: Ph. Chartier, A.A.C.M. Beenackers, G. Grassi (Eds.), Biomass for energy, environment, agriculture and industry. Proc. 8th EC Biomass Conference for Industry Energy and Environment. Vol. 1, Pergamon Press, UK, pp 629-639.

European Commission, 2009. Directive 2009/28/EC of the European Parliament and of the Council of 23 April 2009 on the promotion of the use of energy from renewable sources and amending and subsequently repealing Directives 2001/77/EC and 2003/30/EC. In: Official Journal, L 140, 5/6/2009, pp 16-62. Available from: http://eurlex.europa.eu/legal-content/EN/ALL/?uri=CELEX:32009 L0028

Habyarimana E, Bonardi P, Laureti D, Di Bari V, Cosentino S, Lorenzoni C, 2004. Multilocational evaluation of biomass sorghum hybrids under two stand densities and variable water supply in Italy. Ind. Crops Prod. 20:3-9.

Jamali MK, Kazi TG, Arain MB, Afridi HI, Jalbani N, Sarfraz RA, Baig JA, 2008. A multivariate study: Variation in uptake of trace and toxic elements by various varieties of Sorghum bicolor L. J. Hazardous Mater. 158:644-51.

Lonigro A, Catalano M, Rubino P, 2007. Impiego in agricoltura di acque reflue urbane depurate nel rispetto della sostenibilità ambientale. Ital. J. Agron. 2:217-59.

Mastrorilli M, Campi P, Palumbo AD, Navarro A, Modugno F, Turci V, 2011. Water use efficiency of sorghum cultivated for energy in Mediterranean environments. Proc. 19th European Biomass Conference and Exhibition, 6-10 June 2011, Berlin, Germany, pp 565-568.

Mastrorilli M, Katerji N, Rana G, 1999. Productivity and water use efficiency of sweet sorghum as affected by soil water deficit occurring at different vegetative growth stages. Eur. J. Agron. 11: 207-15.

Smith JL, Doran JW, 1996. Measurement and use of pH and electrical conductivity for soil quality analysis. In: J.W. Doran and A.J. Jones (Eds.), Methods for assessing soil quality. Soil Science Society of America, Madison, WI, USA, pp 169-186.

Steduto P, Katerji N, Puertos-Molina H, Unlu M, Mastrorilli M, Rana G, 1997. Water-use efficiency of sweet sorghum under water stress conditions. Gas exchange investigations at leaf and canopy scales. Field Crops Res. 54:221-34.

Vasilakoglou I, Dhima K, Karagiannidis N, Gatsis T, 2011. Sweet sorghum productivity for biofuels under increased soil salinity and reduced irrigation. Field Crops Res. 120:38-46.

Zegada-Lizarazu W, Monti A, 2012. Are we ready to cultivate sweet sorghum as a bioenergy feedstock? A review on field management practices. Biomass Bioenergy. 40:1-12.

Zhuang P, Shu W, Li Z, Liao B, Li J, Shao J, 2009. Removal of metals by sorghum plants from contaminated land. J. Env. Sci. 21:1432-1437.

Zhang GP, Fukami M, Sekimoto H, 2002. Influence of cadmium on mineral concentrations and yield components in wheat genotypes differing in Cd tolerance at seedling stage. Field Crop Res. 77:93-98. 